\section{Neonatal and pediatric intensive care in Rio de Janeiro State, Brazil: an analysis of bed distribution, 1997 and 2007}

\author{
Terapia intensiva neonatal e pediátrica no Rio de \\ Janeiro, Brasil: distribuição de leitos e análise \\ comparativa de equidade em 1997 e 2007
}

\author{
1 Faculdade de Medicina, \\ Universidade Federal do Rio \\ de Janeiro, Rio de Janeiro, \\ Brasil. \\ 2 Instituto de Puericultura e \\ Pediatria Martagão Gesteira, \\ Universidade Federal do Rio \\ de Janeiro, Rio de Janeiro, \\ Brasil. \\ Correspondence \\ A. P. Barbosa \\ Faculdade de Medicina, \\ Universidade Federal do Rio \\ de Janeiro. \\ Av. Carlos Chagas Filho \\ 373, Edifício do Centro de \\ Ciências da Saúde, Bloco K, \\ Cidade Universitária, \\ Rio de Janeiro, $R J$ \\ 21941-902, Brasil. \\ arnaldoprata@globo.com
}

\section{Abstract}

The objective of this study was to describe the characteristics of neonatal and pediatric intensive care units (ICU) and beds in Rio de Janeiro, correlating with population demands in 1997 and 2007. All neonatal and pediatric ICUs were visited, identifying the availability and type of beds. Comparisons were made between: supply and demand using projected need for beds for the population; public and private ICUs; and geographical regions. In 2007, 95 units were included totaling 1,094 beds (74 units and 1,080 beds in 1997): $51 \%$ public and $48 \%$ private (47\% and 52\% in 1997); $47 \%$ neonatal, $18 \%$ pediatric and 35\% mixed units. Most units were located in the metropolitan area. The distribution of public and private beds was similar in the metropolitan area in both periods; in the interior, public beds tripled. Access has improved, mainly in the interior, but there is still no equity in the distribution of and accessibility to the available beds, with a shortage in the public sector, an excess in the private sector, and a great concentration in the metropolitan area.

Intensive Care; Pediatrics; Neonatology; Health Services Accessibility; Equity
Arnaldo Prata Barbosa 1,2

Antônio José Ledo Alves da Cunha 1,2

\section{Introduction}

Neonatal and pediatric intensive care units (ICU) emerged in the late 1960s and have been developing steadily over the past 40 years, contributing significantly to health care improvements and to a reduction in intra-hospital child mortality $1,2,3,4$. In Brazil, although there was a significant increase in the number of these units and beds available, this growth has occurred without adequate strategic planning. The result, long perceived by users of the system, begins to be clearly evidenced: there is no equity in the distribution of beds, with national and regional inequalities; access is limited, penalizing almost always the poorest segments of the population, and the quality of services varies, ranging from highly sophisticated in some units to others without the minimum required structure 5,6,7. There has been a major effort to identify and correct these distortions: the National Agency for Sanitary Surveillance (Agência Nacional de Vigilância Sanitária - ANVISA) published official guidelines for the establishment and operation of these units 8,9, and the Brazilian Association of Critical Care Medicine (Associação de Medicina Intensiva Brasileira-AMIB) implemented the Census of Brazilian ICUs, a project aimed at improving knowledge of the available structure of ICUs in the country 10,11 . In spite of these efforts, there is still a lack of studies evaluating equity in access to these units, and especially the quality of care they provide. In 1997, we conducted a study analyzing the 
distribution of neonatal and pediatric ICU beds in the Rio de Janeiro State 5. In 2007, we conducted the present study, with similar objectives: (i) to identify the neonatal and pediatric ICUs operating in the state, and the number of active beds, according to geographic region (health regions), public or private status, and type of care (neonatal, pediatric or mixed), comparing supply with demand; (ii) to compare equity in access to neonatal and pediatric ICUs in 1997 and 2007; and (iii) to develop proposals to improve assessments of this specialized area of health care.

\section{Methods}

We studied the neonatal and pediatric ICUs in the State of Rio de Janeiro during two periods (July 1997 to June 1998 in the previous study, and October 2006 to September 2007 in the current one). The units were identified by consulting the list of units registered in the following institutions: (a) the Department of Sanitary Surveillance of the Department of Health and Civil Defense of Rio de Janeiro State (Departamento de Vigilância Sanitária, Secretaria de Estado de Saúde e Defesa Civil do Rio de Janeiro - SESDEC-RJ); (b) the Regional Medical Council of Rio de Janeiro State (Conselho Regional de Medicina do Estado do Rio de Janeiro - CREMERJ); (c) the Rio de Janeiro State Pediatric Society (Sociedade de Pediatria do Estado do Rio de Janeiro - SOPERJ); (d) the Intensive Care Society of Rio de Janeiro State (Sociedade de Terapia Intensiva do Estado do Rio de Janeiro - SOTIERJ); and (e) the Association of Hospitals of the City and the State of Rio de Janeiro. After comparing all the lists, a consolidated one was finally generated, excluding those which were temporarily disabled or not functioning. The ICUs were then classified according to the type of care in: neonatal (age of admission from zero to 28 days), pediatric (age of admission from 28 days to 14 years old), and mixed (both neonates and children could be admitted), and also according to the type of financial support as: public (costs were supported by the Brazilian Unified National Health System SUS) or private (costs were supported by patients or by the Supplementary Health System). The ICUs were then distributed by geographic mesoregions and health regions in the State of Rio de Janeiro, according to, respectively, the definitions of the Brazilian Institute of Geography and Statistics (Instituto Brasileiro de Geografia e Estatística - IBGE. http://mapas.ibge.gov.br/divisao/viewer. htm, accessed on 14/Jan/2010), and the National Health Foundation (Fundação Nacional de Saúde - FUNASA. http:www.funasa.gov.br, accessed on 14/Jun/2010).
The need for intensive care beds was calculated according to the proposition of the Brazilian Ministry of Health (Ministério da Saúde) 12, as follows:

a) for neonatal beds, it took into account the number of births, the percentage of newborns admitted to neonatal intensive care and the average length of stay in these units, by applying the following formula:

Needed neonatal-ICU beds $=$ (live births $\mathrm{x} \%$ of admissions to ICU/number of days in the period) $\mathrm{x}$ average length of stay

b) for pediatric beds, it took into account the number of hospital admissions in the general population, the percentage of pediatric admissions, the percentage of admissions to Pediatric ICUs and the average length of stay (ALS) in these units, by applying the following formula:

Needed pediatric-ICU beds $=$ (number of hospital pediatric admissions $\mathrm{x} \%$ admissions to ICU/number of days in the period) $x$ average length of stay

Access was defined as the capacity of being admitted to an ICU, depending on its public or private nature and also on the geographic distance to be covered. In public sector units, access was considered universal and free of charge, and in private ones, access was limited by the need to cover the cost of care from its own resources or, more commonly, from private health insurance coverage. Access to intensive care and its meeting of population needs were investigated by comparing the observed and expected number of beds, taking into account their public or private nature, and the geographical distribution of the population, according to population counts in 1996 and 2007 (Fundação Centro de Informações e Dados do Rio de Janeiro. http://www.cide.rj.gov.br/down load/RiodeJaneiroemDados.pdf, accessed on 14/ Jun/2010). The number of people with access to private services was considered as $25 \%$ and $32 \%$ of the total population of the Rio de Janeiro State in 1997 and 2007, respectively, according to data from the Brazilian National Agency for Supplementary Health (Agência Nacional de Saúde Suplementar. Taxa de cobertura de serviços. http://www.ans. org.br, accessed on 14/Jun/2010). For the purpose of this study, equity in access was defined as the absence of systematic disparities in the access to neonatal and pediatric intensive care between groups with different levels of underlying socioeconomic status 13,14.

This study was approved by the Ethics Research Committee at the Martagão Gesteira Institute for Child Care and Pediatrics, of the Rio de Janeiro Federal University (Instituto de Puericultura e Pediatria Martagão Gesteira, Universidade Federal 
do Rio de Janeiro - IPPMG/UFRJ). The ICUs and hospitals enrolled were characterized by random numbers and their identities were not revealed.

\section{Results}

Eighty neonatal and pediatric ICUs were identified throughout the state in 1997, and six were excluded for being temporarily out of operation, leaving 74 units in the study. In 2007, 103 were identified and eight were excluded (for similar reasons), leaving 95 units. The regional distribution, compared with the population between zero and 14 years, number of live births per year, public or private nature, type of treatment and total number of beds in both periods is summarized in Table 1. The relationship between the total number of beds and the number of children between 0-14 years old, by geographical health region, is presented in Table 2.

The distribution of beds between public and private, respectively, were 616 (57\%) and 464 (43\%) in 1997 and 639 (58.4\%) and 455 (41.6\%) in 2007. Moreover, the distribution of beds between neonatal, pediatric and in mixed ICUs corresponded respectively to 557 (51.6\%), 150 (13.9\%) and 373 (34.5\%) in 1997 and 681 (62.2\%), 196 (17.9\%) and 217 (19.8\%) in 2007 (Table 3). The largest concentration of units was observed in the metropolitan area, accounting for $92.7 \%$ of beds in 1997 and $80.1 \%$ in 2007 , to serve a proportion of $74 \%$ and $73 \%$ of the state population, respectively, in 1997 and 2007.

Regarding the number of neonatal ICU beds needed, the calculation considered: (i) the number of live births in the Rio de Janeiro State in $1997(268,968)$ and in 2007 (216,876), according to published statistics (Information System on Live Births. http://tabnet.datasus.gov.br/cgi/deftohtm. exe?sinasc/cnv/nvrj.def, accessed on 14/Jan/2010); (ii) the percentage of ICU admissions ( $7 \%$ of all births), according to data previously reported (5); and (iii) the average length of stay of 20 days 5 . Applying those data to the equation already presented, showed a need for 1,032 neonatal intensive care unit beds in 1997 and 833 beds in 2007.

The need for pediatric ICU beds was estimated applying the equation described, based on the following assumptions: (i) the number of public pediatric hospitalizations in Rio de Janeiro was 124,284 in 1997 and 94,294 in 2007, according to data obtained from Health Informatics Department (Departamento de Informática do SUS - DATASUS. http://tabnet.datasus.gov.br/cgi/tabcgi.exe?sih/ cnv/rxrj.def, accessed on 14/Jun/2010) and the number of pediatric hospitalizations from the supplementary private health system (considering $25 \%$ and $32 \%$ of the population in 1997 and in
2007), was 165,712 in 1967 and 138,667 in 2007; (ii) the recommendation of the Ministry of Health that the number of intensive care beds should be $6 \%$ of the general pediatric hospital beds 15; and (iii) the average length of stay of eight days ${ }^{5}$. Results showed that 218 beds were needed in 1997 and 182 beds in 2007 (Table 4). The same methodology was used to calculate the number of needed neonatal and pediatric ICU beds in each health region in both periods (Tables 5 and 6).

\section{Discussion}

The need for neonatal beds is usually defined as one intensive and three intermediary care beds for every 1,000 births per year 16 , therefore a total of four neonatal intensive care unit beds for every 1,000 live births per year. This criterion, in fact, depends on the frequency of premature and high risk births, with large differences between countries, between regions within a country and even between institutions within the same region. While in high-income countries, for example, the rate of newborns with low birth weight $(<2,500 \mathrm{~g})$ is on average $7 \%$, in middle-income countries it is $15 \%$ and in low-income countries $17 \%$. In Brazil, it is currently $8 \%$ on average 17 and $8.9 \%$ in the Rio de Janeiro State 18 . However, not all newborns with low birth weight require intensive care. In the present study we considered $7 \%$ as the percentage of births that would need admission to neonatal intensive care unit and 20 days the average length of stay, based on findings of our previous study 5 . Applying these data we estimated the need for neonatal ICU beds in 1997 to be 1,032 and 833 in 2007 , a ratio of 3.2 for every 1,000 births per year in 1997 and 3,8:1,000 in 2007, which confirmed the need for neonatal intensive care beds (intensive and intermediary) to be 3 to 4 per 1,000 live births per year (in this study we considered together intensive and intermediary care beds). Regarding the need for pediatric intensive care beds, there is still no conclusive study, but the Ministry of Health recommends that 4 to $10 \%$ of pediatric hospital beds be allocated to intensive care 15 .

We observed a significant and meaningful reduction of inequity in relation to the supply and distribution of ICU beds in neonatal and pediatric units between 1997 and 2007 in the state of Rio de Janeiro. This reduction, however, was not uniform and presents particular characteristics that should be considered in the formulation of health policies for this area. The total number of active beds was similar in both periods (1,080 in 1997 and 1,094 in 2007), despite population growth. However, there was a decrease in inequity, with a reduction of beds in the metropolitan area $(1,001$ to $876 ; 12.5 \%$ less $)$ 
Neonatal and pediatric intensive care units in the Rio de Janeiro State, Brazil, 1997 and 2007.

\begin{tabular}{|c|c|c|c|c|c|c|c|c|}
\hline \multirow[t]{3}{*}{ Health region } & \multicolumn{8}{|c|}{1997} \\
\hline & \multirow{2}{*}{$\begin{array}{c}\text { Number of children } \\
\text { (0-14 years) * }\end{array}$} & \multirow{2}{*}{$\begin{array}{l}\text { Number of live } \\
\text { births/year ** }\end{array}$} & \multicolumn{2}{|c|}{ Number of units } & \multicolumn{3}{|c|}{ Type of services } & \multirow{2}{*}{$\begin{array}{c}\text { Number } \\
\text { of beds } \\
\text { Total }\end{array}$} \\
\hline & & & sus & Private & Neonatal & Pediatric & Mixed & \\
\hline Ilha Grande Bay & 36,850 & 3,822 & - & - & - & - & - & - \\
\hline Coastal Lowlands & 139,620 & 8,916 & - & 1 & - & - & 1 & 8 \\
\hline Central-South & 64,282 & 5,418 & - & - & - & - & - & - \\
\hline Middle Paraíba Valley & 203,755 & 14,944 & 1 & 2 & 2 & - & 1 & 31 \\
\hline Greater Metropolitan Rio & $2,584,159$ & 200,957 & 32 & 34 & 30 & 11 & 25 & 1,001 \\
\hline Northwest & 76,894 & 5,248 & - & - & - & - & - & - \\
\hline North & 191,000 & 14,031 & 1 & 1 & - & - & 2 & 22 \\
\hline Mountains & 189,045 & 15,547 & 1 & 1 & - & - & 2 & 18 \\
\hline Total & 3485,605 & 268,968 & 35 & 39 & 32 & 11 & 31 & 1,080 \\
\hline \multirow[t]{3}{*}{ Health region } & \multicolumn{8}{|c|}{2007} \\
\hline & \multirow{2}{*}{$\begin{array}{l}\text { Number of children } \\
\text { (0-14 years) } * \star \star\end{array}$} & \multirow{2}{*}{$\begin{array}{l}\text { Number of live } \\
\text { births/ year \# }\end{array}$} & Num & f units & \multicolumn{3}{|c|}{ Type of Services } & Number \\
\hline & & & sus & Private & Neo & Ped & Mixed & Total \\
\hline Ilha Grande Bay & 74,557 & 3,529 & 1 & - & 1 & - & - & 6 \\
\hline Coastal Lowlands & 178,353 & 9,540 & 2 & 1 & 1 & 1 & 1 & 15 \\
\hline Central-South & 66,865 & 4,070 & 1 & - & 1 & - & - & 4 \\
\hline Middle Paraíba Valley & 202,791 & 10,934 & 2 & 3 & 2 & - & 3 & 68 \\
\hline Greater Metropolitan Rio & $2,639,273$ & 159,810 & 36 & 38 & 36 & 16 & 22 & 876 \\
\hline Northwest & 75,311 & 4,242 & 1 & - & - & - & 1 & 9 \\
\hline North & 192,085 & 12,719 & 4 & 3 & 3 & - & 4 & 76 \\
\hline Mountains & 190,621 & 12,022 & 2 & 1 & 1 & - & 2 & 40 \\
\hline Total & $3,619,856$ & 216,876 & 49 & 46 & 45 & 17 & 33 & 1,094 \\
\hline
\end{tabular}

* According to the Population Count in 1996 (IBGE. http://www.ibge.gov.br);

** According to 1997 data. The total includes additional an 85 births in an unknown region (Information System on Live Births. http://tabnet.datasus.gov.br/ cgi/deftohtm.exe?sinasc/cnv/nvrj.def, accessed on 14/Jun/2010);

*** According to the Population Count in 2007 (IBGE. http://www.ibge.gov.br);

\# According to 2007 data. The total includes an additional ten births in an unknown region (Information System on Live Births. http://tabnet.datasus.gov.br/cgi/ deftohtm.exe?sinasc/cnv/nvrj.def, acessed on 14/Jun/2010).

and a greater availability of beds in inner parts of the state (79 to 218; up 175\%). It is worth mentioning that the reduction of beds in the metropolitan area did not result in inequity in this region, since the number of existing beds is still higher than needed, both in neonatal and pediatric ICUs. Indeed, in the metropolitan area, a 30\% increase was observed in the number of pediatric ICUs with a reduction in the number of mixed units, and an increase of only $7 \%$ in the number of neonatal ICUs, which contributed to correct inequities, previously recorded.
Also, in the inner regions of the state, in 2007 all health regions had ICU beds, which did not occur in 1997. The health regions of Ilha Grande Bay, Central-South and Northwest, where there were no neonatal or pediatric ICU beds in 1997, now have an offer that is still far from ideal, but shows a significant improvement. In Ilha Grande Bay and the Central-South regions, for pediatric and neonatal beds there is still a deficit of $57 \%$ and $75 \%$ respectively. In the Northwest region, the available beds cover only $44 \%$ of neonatal and $28 \%$ of 
Table 2

Relationship between the number of neonatal and pediatric ICU beds and the pediatric population in 1997 and 2007.

\begin{tabular}{lcccc}
\hline Health region & $\begin{array}{c}\text { Number of children } \\
\text { (0-14 years) }\end{array}$ & $\begin{array}{c}\text { Number of beds/ } \\
\text { population (0-14 years) } \\
1997\end{array}$ & $\begin{array}{c}\text { Number of children } \\
\text { (0-14 years) }\end{array}$ & $\begin{array}{c}\text { Number of beds/ } \\
\text { population (0-14 years) }\end{array}$ \\
\hline Ilha Grande Bay & 36,850 & $0: 36,850$ & 74,557 & $1: 12,426$ \\
Coastal Lowlands & 139,620 & $1: 17,452$ & 178,353 & $1: 11,890$ \\
Central-South & 64,282 & $0: 64,282$ & 66,865 & $1: 16,716$ \\
Middle Paraíba Valley & 203,755 & $1: 6,752$ & 202,791 & $1: 2,982$ \\
Greater Metropolitan Rio & $2,584,159$ & $1: 2,581$ & 2639,273 & $1: 3,012$ \\
Northwest & 76,894 & $0: 76,894$ & 75,311 & $1: 8,367$ \\
North & 191,000 & $1: 8, \cdot 681$ & 192,085 & $1: 2,527$ \\
Mountains & 189,045 & $1: 10,502$ & $1: 40,621$ & $1: 4,765$ \\
Total & $3,485,605$ & $1: 3,227$ & 3619,856 & $1: 3,308$ \\
\hline
\end{tabular}

Table 3

Neonatal, pediatric and mixed beds in Rio de Janeiro State, Brazil, in 1997 and 2007 according to public (Brazilian Unified National Health System - SUS) or private nature.

\begin{tabular}{|c|c|c|c|c|c|c|}
\hline \multirow[t]{3}{*}{ Health region } & \multicolumn{2}{|c|}{ ICU-Neonatal } & \multicolumn{2}{|c|}{ Pediatric-ICU } & \multicolumn{2}{|c|}{ Mixed-ICU } \\
\hline & SUS & Private & sus & Private & sus & Private \\
\hline & $1997 / 2007$ & $1997 / 2007$ & $1997 / 2007$ & $1997 / 2007$ & $1997 / 2007$ & $1997 / 2007$ \\
\hline Ilha Grande Bay & $0 / 6$ & $0 / 0$ & $0 / 0$ & $0 / 0$ & $0 / 0$ & $0 / 0$ \\
\hline Coastal Lowlands & $0 / 6$ & $0 / 4$ & $0 / 0$ & $0 / 0$ & $0 / 0$ & $8 / 5$ \\
\hline Central-South & $0 / 4$ & $0 / 0$ & $0 / 0$ & $0 / 0$ & $0 / 0$ & $0 / 0$ \\
\hline Middle Paraíba Valley & $12 / 33$ & $6 / 6$ & $0 / 0$ & $0 / 6$ & $0 / 0$ & $13 / 23$ \\
\hline Greater Metropolitan Rio & $343 / 350$ & $196 / 200$ & $146 / 116$ & $4 / 62$ & $93 / 31$ & $219 / 117$ \\
\hline Northwest & $0 / 0$ & $0 / 0$ & $0 / 0$ & $0 / 0$ & $0 / 9$ & $0 / 0$ \\
\hline North & $0 / 30$ & $0 / 14$ & $0 / 0$ & $0 / 0$ & $10 / 20$ & $12 / 12$ \\
\hline Mountains & $0 / 24$ & $0 / 4$ & $0 / 10$ & $0 / 2$ & $12 / 0$ & $6 / 0$ \\
\hline Total & $355 / 453$ & $202 / 228$ & $146 / 126$ & $4 / 70$ & $115 / 60$ & $258 / 157$ \\
\hline
\end{tabular}

ICU: intensive care units.

Table 4

Existing and needed neonatal and pediatric intensive care beds in the Rio de Janeiro State, Brazil, in 1997 and 2007 and level of adequacy.

\begin{tabular}{|c|c|c|c|c|}
\hline \multirow[t]{2}{*}{ Number of beds } & \multicolumn{2}{|c|}{1997} & \multicolumn{2}{|c|}{2007} \\
\hline & Neonatal & Pediatric & Neonatal & Pediatric \\
\hline Existing * & 855 & 225 & 854 & 240 \\
\hline Needed & 1,032 & 218 & 833 & 182 \\
\hline Adequacy & $-17.0 \%$ & $+3.2 \%$ & $+2.5 \%$ & $+31.9 \%$ \\
\hline
\end{tabular}

* Taking into account that $80 \%$ of beds in the mixed ICU are neonatal. 
Existing and needed neonatal ICU beds, by health region, in the Rio de Janeiro State, Brazil, in 1997 and 2007.

\begin{tabular}{|c|c|c|c|c|c|c|}
\hline \multirow[t]{3}{*}{ Health region } & \multicolumn{3}{|c|}{1997} & \multicolumn{3}{|c|}{2007} \\
\hline & \multirow{2}{*}{$\begin{array}{l}\text { Number of live } \\
\text { births/ year * }\end{array}$} & \multicolumn{2}{|c|}{ Neonatal beds ** } & \multirow{2}{*}{$\begin{array}{l}\text { Number of live } \\
\text { births/ year * }\end{array}$} & \multicolumn{2}{|c|}{ Neonatal beds ** } \\
\hline & & Needed & Existing & & Needed & Existing \\
\hline Ilha Grande Bay & 3,822 & 15 & 0 & 3,529 & 14 & 6 \\
\hline Coastal Lowlands & 8,916 & 34 & 6 & 9,540 & 37 & 14 \\
\hline Central-South & 5,418 & 21 & 0 & 4,070 & 16 & 4 \\
\hline Middle Paraíba Valley & 14,944 & 57 & 28 & 10,934 & 42 & 57 \\
\hline Greater Metropolitan Rio & 200,957 & 771 & 789 & 159,810 & 613 & 668 \\
\hline Northwest & 5,248 & 20 & 0 & 4,242 & 16 & 7 \\
\hline North & 14,031 & 54 & 18 & 12,719 & 49 & 70 \\
\hline Mountains & 15,547 & 60 & 14 & 12,022 & 46 & 28 \\
\hline Total & 268,968 & 1032 & 855 & 216,876 & 833 & 854 \\
\hline
\end{tabular}

* Source: SINASC (Information System on Live Births. http://tabnet.datasus.gov.br/cgi/deftohtm.exe?sinasc/cnv/nvrj.def, accessed on 14/Jun/2010). The total includes an additional ten births from an unknown region;

** Taking into account that $80 \%$ of beds in the mixed ICU, are neonatal.

Existing and needed pediatric ICU beds, by health region, in the Rio de Janeiro State, Brazil, in 1997 and 2007.

\begin{tabular}{|c|c|c|c|c|c|c|c|c|}
\hline \multirow[t]{5}{*}{ Health region } & \multicolumn{4}{|c|}{1997} & \multicolumn{4}{|c|}{2007} \\
\hline & \multirow{4}{*}{$\begin{array}{c}\text { Number of } \\
\text { public pediatric } \\
\text { hospitalizations } \\
\text { ( } 75 \% \text { of total) * }\end{array}$} & \multirow{4}{*}{$\begin{array}{c}\text { Total pediatric } \\
\text { hospitalizations } \\
\text { (projected) } \star \star\end{array}$} & \multicolumn{2}{|c|}{ Pediatric ICU beds } & \multirow{4}{*}{$\begin{array}{c}\text { Number of } \\
\text { public pediatric } \\
\text { hospitalizations } \\
\text { (68\% of total) * }\end{array}$} & \multirow{4}{*}{$\begin{array}{l}\text { Total pediatric } \\
\text { hospitalizations } \\
\text { (projected) ** }\end{array}$} & \multicolumn{2}{|c|}{ Pediatric ICU beds } \\
\hline & & & Needed & Existing & & & Needed & Existing \\
\hline & & & & & & & & \\
\hline & & & & & & & & \\
\hline Ilha Grande Bay Grande & 1,413 & 1,885 & 2 & 0 & 1,159 & 1,704 & 2 & 0 \\
\hline Coastal Lowlands & 1,948 & 2,597 & 4 & 2 & 1,399 & 2,057 & 3 & 2 \\
\hline Central-South & 7,000 & 9,333 & 12 & 0 & 1,464 & 2,152 & 3 & 0 \\
\hline Middle Paraíba Valley & 3,037 & 4,050 & 6 & 3 & 3,975 & 5,846 & 8 & 12 \\
\hline Greater Metropolitan Rio & 95,968 & 127,958 & 168 & 212 & 73,867 & 108,627 & 142 & 209 \\
\hline Northwest & 4,378 & 5,837 & 8 & 0 & 3,621 & 5,325 & 7 & 2 \\
\hline North & 4,478 & 5,970 & 8 & 4 & 4,253 & 6,254 & 8 & 3 \\
\hline Mountains & 6,062 & 8,082 & 10 & 4 & 4,556 & 6,700 & 9 & 12 \\
\hline Total & 124,284 & 165,712 & 218 & 225 & 94,294 & 138,665 & 182 & 240 \\
\hline
\end{tabular}

* Source: DATASUS (Brazilian Unified National Health System. http://tabnet.datasus.gov.br/cgi/tabegi.exe?sih/cnv/rxrj.def, accessed on 14/Jun/2010).

** Sum of total SUS admissions to the estimated number of admissions in the supplementary private health system, according to the rate of coverage.

pediatric beds needed. Moreover, the Middle Paraíba Valley region went from a 50\% deficit of intensive care beds in 1997 to a stable situation in 2007, overcoming projected needs. The North region also has corrected the deficit of neonatal beds observed in 1997 and now offers more than projected, while keeping the deficit of $63 \%$ of pediatric intensive care beds. The Mountains region has increased the supply of pediatric intensive care beds compared to 1997, and supply is now at an adequate level. However, despite doubling the number of neonatal beds, it still shows a deficit of $39 \%$ in this area. Finally, the Coastal Lowlands region continues with the same deficit of $50 \%$ of pediatric intensive care beds, although the availability of neonatal beds increased by $130 \%$. These figures are still insufficient to meet the demand of the population, with an estimated deficit of $62 \%$. 
In summary, considering the adequacy of the total number of beds using the ratio of existing and required pediatric and neonatal intensive care beds, there was found to be a significant increase when comparing 1997 with 2007. While this relationship for neonatal beds was negative in 1997 $(-17 \%)$, and became positive in $2007(+3.2 \%)$, for pediatric beds, it was already positive in 1997 $(+2.5 \%)$, and became even greater $(+32 \%)$ in 2007 .

The distribution of beds remained almost the same in the metropolitan area (58\% private vs. $42 \%$ public), comparing 1997 to 2007 . However, in the inner regions (all other regions, excluding the metropolitan area), the increase in beds occurred mainly in the public sector, an increase of $300 \%$ in the period, from 34 to 142 beds; while in the private sector the increase was about $70 \%$, from 45 to 76 beds, clearly demonstrating a reduction in inequity both in distribution and in access to resources in the inner regions of the state. It is worth noting that, although there is still a significant difference regarding the availability of public and private beds in the metropolitan area, even considering the increase in the population with access to the supplementary private health system (from 25 to $32 \%$ in ten years) there is still a deficit in public beds ( $58 \%$ offer for $68 \%$ of the population), and an excess in the private sector $(42 \%$ of beds for $32 \%$ of the population). In inner regions there was an improvement in equity, with $65 \%$ of public beds and $35 \%$ of private beds. At first sight, working with the average percentage of coverage for the entire state (32\%), these numbers seem appropriate. However, taking into account that this percentage of coverage differs between regions $45 \%$ in the metropolitan area and $15 \%$ in the inner regions) 19 , one realizes that there is also inequity to access to these specialized beds in the interior of the state, with a relatively higher deficit of public beds compared with the metropolitan area.

To improve equity, it is still necessary to invest in more neonatal and pediatric intensive care beds for public access in all health regions of the state. We estimated as $10 \%$ deficit in the metropolitan area and as $20 \%$ shortage in the inner regions still to be overcome. We propose, therefore, an increase of 280 neonatal and 52 pediatric public ICU beds for the Rio de Janeiro State (Table 7).

The development of regional admission centers for the regulation of access to neonatal and pediatric intensive care beds could facilitate decisions on admissions and resources use. If this is coupled with an efficient transport system, as is the case in many parts of the world, it certainly could optimize the use of available resources. Moreover, given the notorious lack of skilled labor to work in these units, an alternative to the creation of new beds in distant regions would be to invest in larger units (30-40 beds) in the state capital, mainly at university or tertiary large hospitals in order to concentrate available resources and harness the expertise of the teams in dealing with this type of patient. Also, the centralization of care reduces the risk of having inner units in the state, with few patients, a recognized factor the at increases morbidity and mortality in intensive care, in face of less expertise accumulated by ICU teams $20,21,22$. This alternative, which is already adopted in many countries, reinforces the need to invest in an efficient referral system for transferring more severe patients to tertiary centers in the metropolitan area 23,24 .

Although in both periods we included most active ICUs, one limitation of the present study was that those ICUs that were disabled or temporarily closed were not included during data collection. We believe, however, that this fact does not change substantially the results nor alter the trends we have found.

\section{Conclusions}

This study contributes to a better understanding of the current situation of pediatric and neonatal intensive care beds in the Rio de Janeiro State, and presents a dynamic view of the inequities in this area in a more extended period. It can be concluded that there was a reduction in inequity over ten years, although investments are still necessary in the public sector to increase the availability of beds and improve access to this specialized care. Our results may contribute to the formulation of more effective and efficient health policies for improving equity in this area.

\section{Table 7}

Suggested increase in the number of neonatal and pediatric intensive care beds for public access.

\begin{tabular}{lcc}
\hline Health region & Neonatal & Pediatric \\
\hline Ilha Grande Bay & 12 & 4 \\
Coastal Lowlands & 30 & 4 \\
Central-South & 12 & 4 \\
Middle Paraíba Valley & 12 & 10 \\
Greater Metropolitan Rio & 180 & 20 \\
Northwest & 10 & 6 \\
North & 12 & 4 \\
Mountains & 12 & - \\
Total & 280 & 52 \\
\hline
\end{tabular}




\section{Resumo}

Descrever as características das unidades de terapia intensiva (UTI) neonatais e pediátricas e leitos no Rio de Janeiro, Brasil, correlacionando com demandas da população em 1997 e 2007. UTIs neonatais e pediátricas foram visitadas, identificando-se o tipo e disponibilidade de leitos. Foram feitas comparações entre: a oferta e a demanda projetada da necessidade de leitos para a população, a natureza pública ou privada das UTIs e regiões geográficas. Em 2007, 95 unidades foram incluídas, totalizando 1.094 leitos (74 e 1.080 leitos em 1997): $51 \%$ públicas e $48 \%$ privadas (47\% e $52 \%$ em 1997); $47 \%$ neonatais, $18 \%$ pediátricas e $35 \%$ mistas. A maioria estava localizada na região metropolitana. A distribuição dos leitos públicos e privados foi semelhante na região metropolitana em ambos os periodos, no interior os públicos triplicaram. O acesso melhorou, principalmente no interior, mas ainda não há equidade na distribuição e no acesso aos leitos disponíveis, com falta no setor público, excesso no privado, e grande concentração na região metropolitana.

Cuidados Intensivos; Pediatria; Neonatologia; Acesso aos Serviços de Saúde; Equidade

\section{Contributors}

A. P. Barbosa designed and planned the study, supervised the data collection, analyzed the data, and wrote and approved the manuscript. A. J. L. A. Cunha designed and planed the study, analyzed the data, and wrote and approved the manuscript.

\section{Acknowledgements}

The authors thank all those who contributed directly or indirectly with the data collection, especially Edimilson Migowski, Marcia Georgakapoulos, Jandra Lacerda, Elgita Diniz, Cleyde Vanzillotta, Vanessa Soares and Sergio Gama.

\section{References}

1. Stark AR; American Academy of Pediatrics Committee on Fetus and Newborn. Levels of neonatal care. Pediatrics 2004; 114:1341-7.

2. Pollack MM, Katz RW, Ruttimann UE, Getson PR. Improving the outcome and efficiency of pediatric intensive care. Crit Care Med 1988; 16:11-7.

3. Pollack MM, Alexander SR, Clarke N, Ruttimann UE, Tesselaar HM, Bachulis AC. Improved outcomes from tertiary center, pediatric intensive care: A statewide comparison of tertiary and nontertiary care facilities. Crit Care Med 1991; 19:150-9.
4. Phibbs CS, Baker LC, Caughey AB, Danielsen B, Schmitt SK, Phibbs RH. Level and volume of neonatal intensive care and mortality in verylow-birth-weight infants. N Engl J Med 2007; 356: 2165-75.

5. Barbosa AP, Cunha AJLA, Carvalho ERM, Portella AF, Andrade MPF, Barbosa MCM. Terapia intensiva neonatal e pediátrica no Rio de Janeiro: distribuição de leitos e análise de eqüidade. Rev Assoc Med Bras 2002; 48:303-11.

6. Souza DC, Troster EJ, Carvalho WB, Shin SH, Cordeiro AMG. Disponibilidade de unidades de terapia intensiva pediátrica e neonatal no Município de São Paulo. J Pediatr (Rio J.) 2004; 80:453-60. 
7. Barbosa AP. Terapia intensiva neonatal e pediátrica no Brasil: o ideal, o real e o possível. J Pediatr (Rio J.) 2004; 80:437-8.

8. Brasil. Agência Nacional de Vigilância Sanitária. Resolução RDC nº. 50/2002. http://www.anvisa. gov.br/legis/resol/2002/50_02rdc.pdf (accessed on 14/Jun/2010).

9. Brasil. Agência Nacional de Vigilância Sanitária. Resolução RDC no. 7, de 24/02/2010. http:/ /bvsms. saude.gov.br/bvs/saudelegis/anvisa/2010/res0007 _24_02_2010.html (accessed on 14/Jun/2010).

10. Associação de Medicina Intensiva Brasileira. 2o Anuário Brasileiro de UTI's. São Paulo: Associação de Medicina Intensiva Brasileira; 2004.

11. Associação de Medicina Intensiva Brasileira. Relatório do 3o Censo Brasileiro de UTIs, 2009. http:// www.amib.org.br/pdf/CensoAMIB2010.pdf (accessed on 14/Jun/2010).

12. Ministério da Saúde. Equipamentos para estabelecimentos assistenciais de saúde: planejamento e dimensionamento. Brasília: Ministério da Saúde; 1994.

13. Whitehead M. The concepts and principles of equity in health. Int J Health Serv 1992; 22:429-45.

14. Braveman P, Gruskin S. Defining equity in health. J Epidemiol Community Health 2003; 57:254-8.

15. Brasil. Ministério da Saúde. Portaria no. 3432/GM, de 12 de agosto de 1998. Diário Oficial da União 1998; 13 ago.

16. Fiori RM. Regionalização da assistência perinatal. In: Miranda LEV, Lopes JMA, organizadores. Manual de perinatologia. Rio de Janeiro: Sociedade Brasileira de Pediatria; 1991. p. 17-20.
17. Fundo das Nações Unidas para a Infância. Situação mundial da infância 2009. Saúde materna e neonatal. Brasília: Fundo das Nações Unidas para a Infância; 2009.

18. Fundo das Nações Unidas para a Infância. Situação mundial da infância 2008. Cadernos Brasil. Brasília: Fundo das Nações Unidas para a Infância; 2008.

19. Pinto LF. O setor de saúde suplementar: Acesso e cobertura populacional. http://www.ans.gov.br/ data/files/8A958865266CAFE201267FB27430225 9/TT_AS_01_LFelipePinto_CoberturaEAcesso.pdf (accessed on 14/Jun/2010).

20. Pollack MM, Patel KM, Ruttimann E. Pediatric critical care training programs have a positive effect on pediatric intensive care mortality. Crit Care Med 1997; 25:1637-42.

21. Pollack MM, Koch MA; NIH-District of Columbia Neonatal Network. Association of outcomes with organizational characteristics of neonatal intensive care units. Crit Care Med 2003; 31:1620-9.

22. Pollack MM. Pediatric intensive care quality factors. J Trauma 2007; 63(6 Suppl):S143-5.

23. Ajizian SJ, Nakagawa TA. Interfacility transport of the critically ill pediatric patient. Chest 2007; 132;1361-7.

24. Departamento de Ações Programáticas e Estratégicas, Secretaria de Atenção à Saúde. Manual de orientações sobre o transporte neonatal. Brasília: Ministério da Saúde; 2010.

Submitted on $17 /$ Jun/2010

Final version resubmitted on $02 / \mathrm{Feb} / 2011$

Approved on 08/Feb/2011 